\title{
Using Bagasse Ash as a Substitute for the Preparation of Cement Mortar
}

\author{
C. Bernabe Reyes ${ }^{1}$, W. Martinez Molina ${ }^{1}$, E. M. Alonso Guzman ${ }^{1}$, H. L. Chavez García ${ }^{1}$, A. A. Torres Acosta ${ }^{2}$, \\ J. T. Perez Quiroz ${ }^{2}$, C. Lara Gómez ${ }^{1}$, F. M. Gonzalez Valdez ${ }^{1}$, M. Arreola Sanchez ${ }^{1}$ and J. A. Bedolla Arroyo ${ }^{3}$ \\ ${ }^{1}$ School of Civil Engineering, University Michoacana de San Nicolas de Hidalgo, Morelia, Michoacan, Mexico, 58040 \\ ${ }^{2}$ Mexican Institute of Transport, Ministry of Communications and Transport, Sanfandila, Queretaro, Mexico, 76703 \\ ${ }^{3}$ Faculty of Architecture, Universidad Michoacana de San Nicolas de Hidalgo, Morelia, Michoacan, Mexico, 58040
}

\begin{abstract}
A ton of Portland cement (CP) generates about one tonne of $\mathrm{CO}_{2}$, accounting for $5 \%$ of all $\mathrm{CO}_{2}$ emissions in the world, which affects negatively the greenhouse effect. Developments relating to the use of bagasse ash (CBC) as a substitute for $\mathrm{CP}$ in making mortars are shown in this study.
\end{abstract}

Keywords- mortars; corrosion; pozzolans

\section{INTRODUCTION}

Currently many technologies are being used for the benefit of the environment, but these developments fail to offset all $\mathrm{CO}_{2}$ emissions, and cement plants contribute significantly to climate change around the world, representing about $5 \%$ of the anthropogenic damage [1], which is worrying given the negative impact associated with greenhouse gases $[2,3]$. The material used in the construction industry is hydraulic concrete $(\mathrm{CH})$, whose base is $\mathrm{CP}$, and due to its large scale of production emissions are generated. An alternative that can minimize damage to the environment and the cost of $\mathrm{CH}$ is the use of mineral additives such as limestone powder, natural pozzolans and fly ash, adding these to $\mathrm{CH}$ as separate ingredients before or during mixing [4].

Agricultural and industrial wastes from the sugar industry, mainly sugar cane bagasse ash (CBC) and cane straw ash (CPC), have pozzolanic activity due to the high content of silica $\left(\mathrm{SiO}_{2}\right)$ present in these materials $[5,6]$.

A behavioural assessment of the addition of cement substitute materials in the preparation of mortar and/or concrete and its effect on corrosion resistance can be determined using electrochemical techniques such as linear polarization resistance $[7,8,9]$, Tafel extrapolation $[7,8,9]$ and electrochemical impedance spectroscopy [10].

In agricultural waste, pozzolanic activity depends mainly on the combustion temperature, which should be between $400{ }^{\circ} \mathrm{C}$ and $800{ }^{\circ} \mathrm{C}[6,5]$ to prevent the formation of crystalline phases of silica as the product of high temperatures in the combustion. The ash produced under these conditions is considered to be of good quality.

In this paper we propose to add $\mathrm{CBC}$ mortars to $\mathrm{CP}$ in 5 different weight ratios, using electrochemical techniques to analyze the performance against corrosion experienced by the grade 60 steel embedded in them.

\section{Methodology}

\section{A. Materials}

The cement used in making the mortar specimens was a Portland composite cement (CPC) 30R RS [11]. The sand used as aggregate in mortars with substitutions of control CBC and mortars (TH) was extracted from Huajúmbaro River, State of Michoacan, and sieved using ASTM No. 16 mesh and retained on ASTM No. 30 mesh. Lerma River sand was used in the preparation of the control mortar (TL) for comparative analysis, and was monitored under the same conditions as the $\mathrm{TH}$. The CBC was obtained from the sugar mill located in the town of Taretan, Michoacan, Mexico. The CBC underwent a treatment of drying and screening, using particles passing the ASTM No. 200 sieve $(0.074 \mathrm{~mm})$ to prepare the mortar. The amount of $\mathrm{CBC}$ used as replacement by weight of cement to manufacture the different mortars was $5 \%, 10 \%, 15 \%, 20 \%$ and $30 \%$. Water used in the manufacture of mortars was obtained from the laboratory storage. We used a solution containing $3.5 \mathrm{wt} \% \mathrm{NaCl}$ to simulate an aggressive environment for chlorides. The reinforcing elements were built with rods of 7/32" diameter, grade 60 steel.

The $\mathrm{CBC}$ and the $\mathrm{CP}$ were characterized by the X-ray fluorescence (XRF) technique to determine the chemical composition.

\section{B. Manufacture of Specimens}

Two types of specimens were fabricated: cubes $5 \mathrm{~cm} \times 5 \mathrm{~cm}$ $\mathrm{x} 5 \mathrm{~cm}$ and prisms $8 \mathrm{~cm} \times 5 \mathrm{~cm} \times 1.5 \mathrm{~cm}$. The first were used for testing of the mortars to study their mechanical and physical characterization. The prisms were used to electrochemically characterize the reinforcing steel embedded in these mortars and exposed to cycles of wetting and drying with simulated seawater. Cube type specimens were prepared in metal molds according to the standard procedure $[12,13]$. The prismatic specimens were prepared in acrylic molds $1.5 \mathrm{~cm} \times 5 \mathrm{~cm} \times 8 \mathrm{~cm}$, with perforations to allow the inclusion of corrugated grade 60 steel rods 7/32" in diameter [14]. Mixing of the mortar materials was performed in a plastic container with a capacity of 19 liters using a power drill with $3500 \mathrm{rpm}$ and $750 \mathrm{~W}$, accessory mixing blades, with a mixing time of $3 \mathrm{~min}$. For the design of the mixture prior to the preparation of the specimens, tests were performed to determine the amount of water necessary to obtain a flow of $110 \pm 5$ in the mortars, with a 
water/cement ratio of 1.01 obtained [15]. For each substitution, cubic specimens of $5 \mathrm{~cm} \times 5 \mathrm{~cm} \times 5 \mathrm{~cm}$ were prepared, which underwent simple compression tests, and electrical resistivity and ultrasonic pulse velocity tests $[12,16,17]$.

\section{Physical And Mechanical Tests}

The physical tests were ultrasonic pulse velocity (VPU) [16] and electrical resistivity (ER) [17]. The equipment used for the test was a dual VPU machine, model 58-e0049/B (CONTROLS), with a frequency range of 24 to $150 \mathrm{kHz}$.

The electrical resistance measurements were performed with a resistometer (Nilsson). The mechanical tests were performed in a universal machine (Tinius Olsen) [12].

\section{ELECTROCHEMICAL TESTS}

The electrochemical technique used to quantify the rate of corrosion was linear polarization resistance (LPR) [7, 8, 9]. As the working electrode, grade 60 steel was used, the counterelectrode was stainless steel plate, AISI 316L specification [18] standard, and for the reference electrode saturated calomel electrode was used. The electrolyte used was 3.5\% sodium chloride by weight. The specimens were not subjected to the curing process, but placed in plastic bags to avoid interaction with the $\mathrm{CO}_{2}$, and immersed for 90 days in the $\mathrm{NaCl}$ solution. A Gamry 600 potentiostat was used according to the ASTM G3, G5 and G59 standards. The tests were conducted with the specimens and electrodes immersed in the $\mathrm{NaCl}$ solution. The steel contact area was $13.67 \mathrm{~cm}^{2}$, and the interval test was performed from $-0.02 \mathrm{~V}$ to $+0.02 \mathrm{~V}$, with a scan rate of 0.125 $\mathrm{mV} / \mathrm{s}$. After obtaining the Rp value, we proceeded to calculate the corrosion current density (icorr) using the equation of Stern and Geary (1957), which is shown in Equations 1 and 2 [9]:

$$
\begin{aligned}
& i_{c o r}=\frac{E}{F_{p}} \\
& B=\frac{b_{g} b_{c}}{\left[2.3030 b_{c}+b_{c} x\right]}
\end{aligned}
$$

where $b_{a}$ and $b_{c}$ are the slope Tafel anodic and cathodic, respectively [8].

We resorted to using a $\mathrm{B}$ value of $26 \mathrm{mV}$, which indicates a free corrosion phenomenon. This value is between 60 and $120 \mathrm{mV} /$ decade $[20,21]$.

\section{RESULTS}

\section{A. Analysis of $X$-ray Fluorescence}

$\mathrm{XRF}$ results for the $\mathrm{CBC}$ and the $\mathrm{CP}$ are presented in Table 1. It can be seen that the concentrations of silica oxide in the $\mathrm{CBC}$ are above $50 \%$, which is relatively low compared with those reported by other authors [11]. Ash CBC is classified as class N according to ASTM C618 standard, as a result of the calcining process; however this is not within the classification of pozzolan, since the sum of $\mathrm{SiO}_{2}+\mathrm{Al}_{2} \mathrm{O}_{3}+\mathrm{Fe}_{2} \mathrm{O}_{3}$ is below $70 \%$ [22].

TABLE I. CHEMICAL COMPOSITION IN PERCENT BY WEIGHT OF MATERIALS USED IN SUBSTITUTIONS, OBTAINED BY X-RAY FLUORESCENCE, ASTM E 2465 [23]

\begin{tabular}{|c|c|c|c|c|c|c|c|c|c|c|}
\hline \multicolumn{10}{|c|}{ Composition of the cane bagasse ash } \\
\hline Material & $\begin{array}{c}\mathrm{SiO}_{2} \\
(\%)\end{array}$ & $\begin{array}{c}\mathrm{Al}_{2} \mathrm{O}_{3} \\
(\%)\end{array}$ & $\begin{array}{c}\mathrm{TiO}_{2} \\
(\%)\end{array}$ & $\begin{array}{c}\mathrm{Fe}_{2} \mathrm{O}_{3} \\
(\%)\end{array}$ & $\begin{array}{c}\mathrm{MgO} \\
(\%)\end{array}$ & $\begin{array}{c}\mathrm{MnO} \\
(\%)\end{array}$ & $\begin{array}{c}\mathrm{CaO} \\
(\%)\end{array}$ & $\begin{array}{c}\mathrm{Na}_{2} \mathrm{O} \\
(\%)\end{array}$ & $\begin{array}{c}\mathrm{K}_{2} \mathrm{O} \\
(\%)\end{array}$ & $\begin{array}{c}\mathrm{SO}_{3} \\
(\%)\end{array}$ \\
\hline $\mathrm{CBC}$ & 56.62 & 4.293 & 0.422 & 5.488 & 1.573 & 0.227 & 2.013 & 0.24 & 2.178 & 0.244 \\
\hline $\begin{array}{c}\mathrm{CPC} 30 \mathrm{R} \\
\mathrm{RS}\end{array}$ & 23.88 & 4.997 & 0.217 & 2.972 & 0.88 & 0.096 & 54.6 & 1.23 & 1.666 & 3.791 \\
\hline
\end{tabular}

Research was conducted by Martirena Hernandez in 2000 on the chemistry of the $\mathrm{CBC}$ from the sugar agroindustrial complex "October 10", in the province of Villa Clara in Cuba, using the technique of X-ray fluorescence and the results reported are shown in Table 2 [6].

TABLE II. CHEMICAL COMPOSITION OF THE CBC FROM THE SUGAR AGROINDUSTRIAL COMPLEX "OCTOBER 10", IN THE PROVINCE OF VILLA CLARA IN CUBA

\begin{tabular}{|c|c|c|c|c|c|c|c|c|c|c|}
\hline \multicolumn{10}{|c|}{ Composition of the cane bagasse ash } \\
\hline & $\begin{array}{c}\mathrm{SiO}_{2} \\
(\%)\end{array}$ & $\begin{array}{c}\mathrm{Al}_{2} \mathrm{O}_{3} \\
(\%)\end{array}$ & $\begin{array}{c}\mathrm{Fe}_{2} \mathrm{O}_{3} \\
(\%)\end{array}$ & $\begin{array}{c}\mathrm{TiO}_{2} \\
(\%)\end{array}$ & $\begin{array}{c}\mathrm{MgO} \\
(\%)\end{array}$ & $\begin{array}{c}\mathrm{K}_{2} \mathrm{O} \\
(\%)\end{array}$ & $\begin{array}{c}\mathrm{Na}_{2} \mathrm{O} \\
(\%)\end{array}$ & $\begin{array}{c}\mathrm{P}_{2} \mathrm{O}_{5} \\
(\%)\end{array}$ & $\begin{array}{c}\mathrm{SO}_{3} \\
(\%)\end{array}$ & $\begin{array}{c}\mathrm{CaO} \\
(\%)\end{array}$ \\
\hline $\mathrm{CBC}$ & 72.74 & 5.26 & 3.92 & 0.32 & 2.78 & 3.47 & 0.84 & 1.59 & 0.13 & 7.99 \\
\hline
\end{tabular}

\section{B. Morphology and Particle Size}

$\mathrm{CBC}$ has an elongated morphology and porous particles, because of fibres of the sugarcane, from which it is obtained, with an average particle size of $48.27 \mu \mathrm{m}$, Figure 1. The average characteristic particle size of the CPC is $17.31 \mu \mathrm{m}$, which is an indication that the $\mathrm{CBC}$ has a smaller surface area, Figure 2.

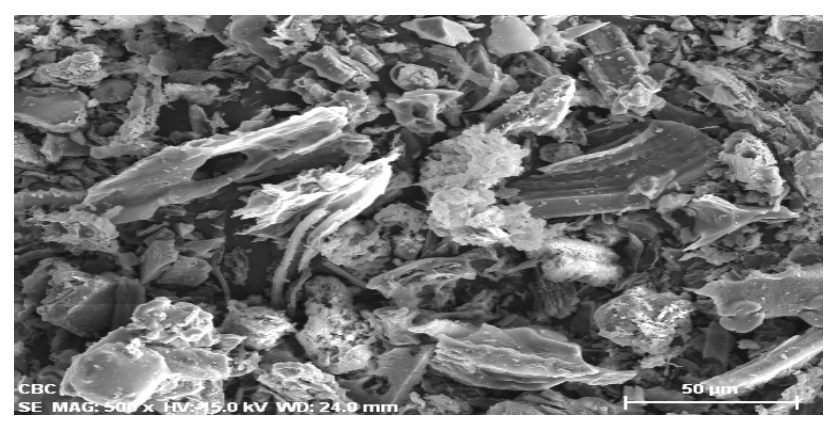

FIGURE I. Morphology Of CBC Analyzed In SEM At 500x

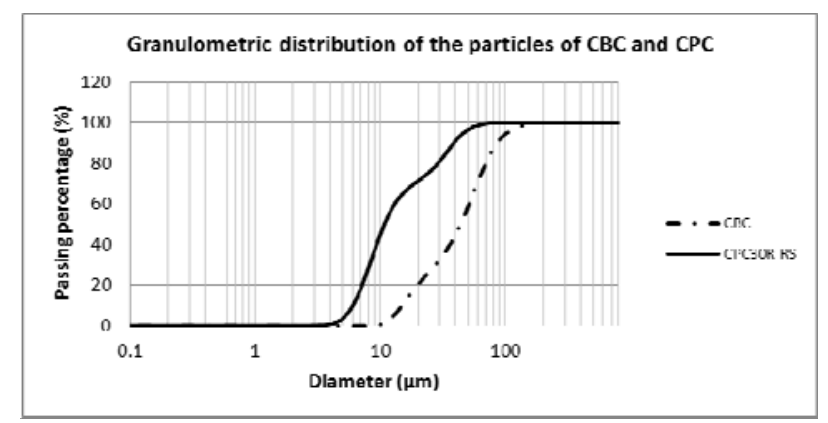

FIGURE II. PARTICLE SIZE DISTRIBUTION OF CBC AND CPC 30R-RS 


\section{Trials in Mortar Fluid}

A water-cement $(\mathrm{a} / \mathrm{c})$ ratio of 1.01 in the mortar mixtures obtained from the test flow table was used, which is in the range of $110 \pm 5$ percent for the equipment flow test $[13,15]$.

\section{Compression Test}

The results of compressive strength testing of the mixtures used are shown in Figure 3 for 14, 28, 45, 90 and 180 days after the cubes were manufactured. These values are compared with the results of the control mortar cubes, where no $\mathrm{CBC}$ $(0 \%)$ was used. It can be seen that the compressive strengths increase with time of curing, up to 45 days. After 90 days, efforts decreased for all the percentages of substitution, which increased again to 180 days, being substitutions of $20 \%$ and $30 \%$ which reached maximum resistances. It is observed that the mortar with $20 \%$ replacement showed the best compression performance and the mortar with $15 \%$ the least favorable result. The index of pozzolanic activity, obtained by the results of compression of the mortar cubes with a replacement of $20 \%$ of $\mathrm{CBC}$, exceeds $75 \%$ of the strength relative to the control, which is considered as the lower limit established in the ASTM C618 standard $[2,3]$.

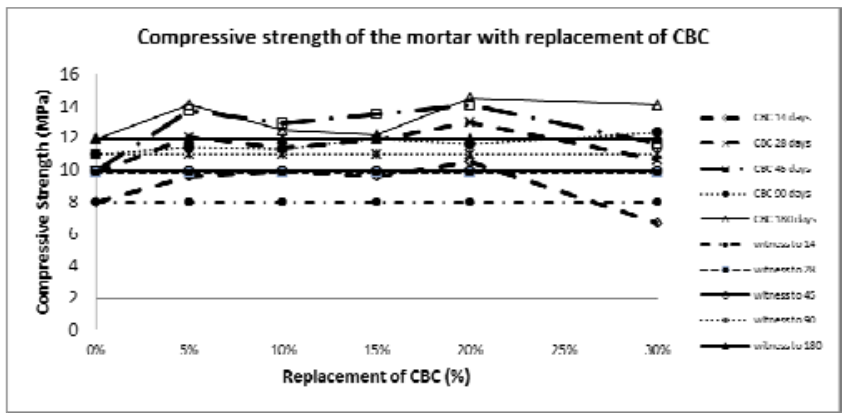

FIGURE III. TEST RESULTS OF COMPRESSIVE STRENGTH IN MORTARS WITH CBC SUBSTITUTION

\section{E. Ultrasonic Pulse Rate}

As shown in Figure 4, the values of ultrasonic pulse velocity (VPU) for the mixtures with additions of $\mathrm{CBC}$ were lower than the controls, from which a lower density in the mortar with the replacement can be inferred. Another interesting point that was observed in the VPU results was that initially, and at 14 and 28 days, the values obtained in the control mixtures were higher than those obtained with mixtures spiked with $\mathrm{CBC}$.

\section{F. Electrical Resistivity}

The resistive behaviour of mortars with $\mathrm{CBC}$ substitution has results superior to $10 \mathrm{k}-\mathrm{cm}$, exceeding by more than twice the control mortars, except for the substitution of $30 \%$. The results are shown in Figure 5, obtained from tests on the cubes at ages of 14, 28, 45 and 90 days on specimens cured by immersion. Under these conditions and taking into account the approach of the RED DURAR, the mortars present a moderate risk of corrosion of the structures immersed in them, the best performance being presented by substitutions of 10 and $20 \%$ [19].

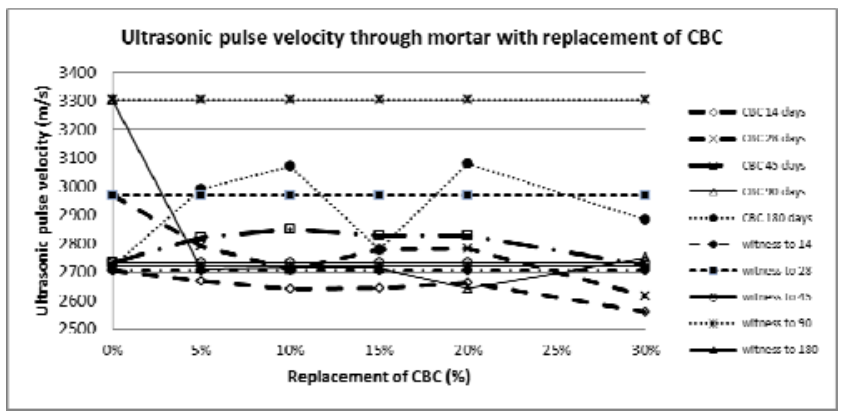

FIGURE IV. RESULTS OF PULSE VELOCITY TESTS FOR MORTARS WITH CBC SUSBSTITUTION

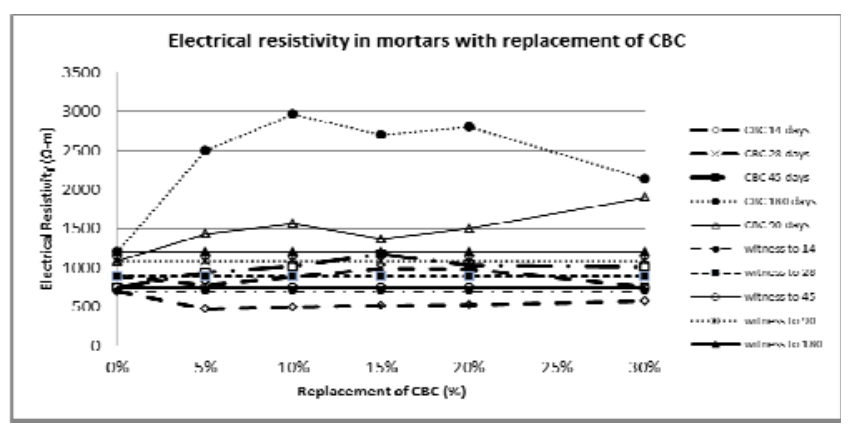

FIGURE V. TEST RESULTS OF ELECTRICAL RESISTIVITY IN MORTARS WITH REPLACEMENT CBC

\section{G. Corrosion Potential (Ecorr)}

According to the ASTM C876 standard, if the potential of an area is more positive than $-0.20 \mathrm{~V}$ there is a $90 \%$ probability that corrosion is not occurring in the steel when carrying out the experimentation; if in the range of -0.20 to $0.35 \mathrm{~V}$, it is likely that there is corrosion; and for potentials which are more negative than $-0.35 \mathrm{~V}$ there is no more than a $90 \%$ probability that steel corrosion is occurring at the time of conducting the test [25]. Table 3 shows the risk rating criteria for the corrosion of reinforcing steel by measuring the corrosion potentials presented (corr), according to the Manual of the RED DURAR [19].

TABLE III. POTENTIAL ENDPOINT STEEL CONCRETE VS Cu / $\mathrm{CuSO}_{4}$

\begin{tabular}{|c|c|c|c|}
\hline CONDITION & $\begin{array}{c}\text { POTENTIAL } \\
(\text { E)(ESC) }\end{array}$ & OBSERVATIONS & $\begin{array}{c}\text { RISK OF } \\
\text { DAMAGE }\end{array}$ \\
\hline State liability & $(+0.200 \mathrm{a}-0.200)$ & $\begin{array}{c}\text { Lack of } \mathrm{Cl} \mathrm{pH}>12.5 \quad \mathrm{H}_{2} \mathrm{O} \\
(\mathrm{HR}+)\end{array}$ & Negligible \\
\hline Localized corrosion & $(-0.200 \mathrm{a}-0.600)$ & $\mathrm{Cl}_{2} \mathrm{O}_{2}, \mathrm{H}_{2} \mathrm{O}(\mathrm{HR}+)$ & High \\
\hline Uniform corrosion & $(-0.150 \mathrm{a}-0.600)$ & $\begin{array}{c}\text { Carbonated } \mathrm{O}_{2}, \mathrm{H}_{2} \mathrm{O}, \\
(\mathrm{HR}+)\end{array}$ & Moderately high \\
& $(+0.200 \mathrm{a}-0.150)$ & $\begin{array}{c}\text { Carbonated } \\
(\mathrm{HR}-)\end{array}$ \\
$\mathrm{O}_{2}$, seco & Low \\
\hline Uniform corrosion & $(<-400 \mathrm{a}-0.600)$ & $\mathrm{Cl}^{-}$high, $\mathrm{H}_{2} \mathrm{O}$ o Carbonated \\
$\mathrm{H}_{2} \mathrm{O},(\mathrm{HR}+)$ & High \\
\hline
\end{tabular}

Figure 6 shows the values of corrosion potential (E corr) obtained when monitoring prisms with embedded steel rods. It can be seen that these rods were always in a range of values between -600 and $-700 \mathrm{mV}$ (vs ESC), which indicates that the steel was active at all times. 


\section{H. Corrosion Current Density (Icorr)}

Rated icorr values in terms of life are given in Table 4:

TABLE IV. CLASSIFICATION OF $\mathrm{i}_{\text {corr }}$ VALUES IN TERMS OF LIFE [19]

\begin{tabular}{|c|l|}
\hline $\mathbf{i}_{\text {corr }}\left(\boldsymbol{\mu A} \mathbf{A} / \mathbf{c m}^{2}\right)$ & Corrosion Level \\
\hline$<0.1$ & Negligible \\
\hline $0.1-0.5$ & Moderated \\
\hline $0.5-1$ & High \\
\hline$>1$ & Very high \\
\hline
\end{tabular}

The $i_{\text {corr }}$ values obtained are shown in Figure 7 , in which the results indicate a very high level of corrosion. Lower values of $i_{\text {corr }}$ are presented by the control mortars, and the highest value found is for the $30 \%$ substitution. The maximum values detected in the laboratory tests are in the order of 100 $200 \mathrm{uA} / \mathrm{cm}[19]$.

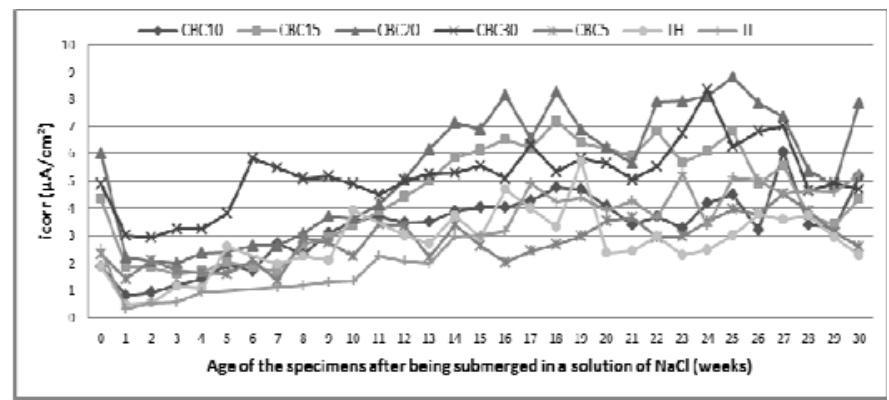

FIGURE VI. CORROSION CURRENT DENSITY (ICORR) VS TIME. TH:

CONTROL MORTAR MADE WITH SAND FROM HUAJÚMBARO

RIVER. TL: CONTROL MORTAR MADE FROM LERMA RIVER SAND

\section{CONCLUSIONS}

Using an a/c of 1.01 is very high, which together with the lack of cured in the prismatic specimens with embedded steel bars, leads to a mortar with a lot of pores, which has low electrical resistance and higher permeability. Under these conditions, when submerging the specimens in the solution of sodium chloride $(\mathrm{NaCl})$, chloride ions activate the steel and the corrosion phenomenon begins. These statements are based on the corrosion potential and current density results obtained, which show that the steel was always active, with potential ranging between -600 and $-700 \mathrm{mV}$, presenting a high level of corrosion. The level of corrosion increases depending on the degree of substitution of the ash, with the worst result shown for the steel bar embedded in the mortar with the $30 \%$ replacement value. In the cured condition by dipping the mortars substituted with $\mathrm{CBC}$, the results of the physicomechanical tests are favorable. The pozzolanic activity index obtained with the mortar having $\mathrm{CBC}$ substitution increases the resistance by $32.28 \%$ over the control mortar. The highest resistivities are presented by the mortars with substitutions of 10 and $20 \%$, overtaking the control at $100 \%$, except the replacement percentage of $30 \%$. One of the most striking effects is the generation of ashes, from which it can be concluded that when they are used as cement substitutes two objectives are met: it is possible to use materials considered as agro-industrial waste for construction of infrastructure and at the same time to reduce the amount of CP used.

\section{ACKNOWLEDGMENT}

The support of the Coordination of Scientific Research of the Universidad Michoacana de San Nicolas de Hidalgo and the Ministry of Education, PROMEP, is appreciated.

\section{REFERENCES}

[1] Chennoufi, L. and Hoagland-Grey, H. (2010) Guidelines for cement: Approach to Funding Reconciliation Cement Factories objectives on climate change. Inter-American Development Bank, p. 5.

[2] Escalante, J.I. and Navarro Gomez, A. (2011) Characterization of Portland cement mortars replaced by metakaolin low purity. ALCONPAT Magazine, pp. 156-169.

[3] Ruchansky, A. (2013) Possibilities of using bagasse ash as a mineral admixture in Portland cement. CONPAT, Uruguay.

[4] Sahmaran, M. and Christianto, H.A. (2006) The effect of chemical admixtures and mineral additives on the properties of self-compacting mortars. Cement \& Concrete Composites, 28, 432-440.

[5] Malhotra, S.K. (1993) Cementitious binders from agro-industrial byproducts. Basin News. U.K.

[6] Martirena Hernandez, J.F. and Betancourt Rodriguez, J. (2000) Pozzolanic properties of waste of sugar industries (first part). Building Materials, Spain, 50, 71-72.

[7] ASTM-G3. (2004) Standard Practice for Conventions Applicable to Electrochemical Measurements in Corrosion Testing.

[8] ASTM-G5. (2004) Standard Reference Test Method for Making Potentiostatic and Potentiodynamic Anodic Polarization Measurements.

[9] ASTM-G59. (2003) Standard Test Method for Conducting Potentiodynamic Polarization Resistance Measurements.

[10] ASTM-G106. (2004) Standard Practice for Verification of Algorithm and Equipment for Electrochemical Impedance Measurements.

[11] ASTM-C150. (2005) Standard Specification for Portland Cement.

[12] ASTM-C109. (2002) Standard Test Method for Compressive Strength of Hydraulic Cement Mortars (using 2-in or 50-mm Cube Specimens).

[13] NMX-C-061. (2010) Determining the compressive strength of cementitious Hydraulic.

[14] Andrade, C. and Gonzalez, J. (1978) Quantitative electrochemical determination of the corrosion rate of a steel construction. Evaluation of susceptibility to pitting. Part II: Essays in mortars. (Scientific CS, Ed.). Building Materials, 28, No. 169.

[15] NMX-C144. (2004) ONNCCE Construction Industry - Hydraulic Cement - Specifications and Test Methods. Mexico: s.n.

[16] ASTM-C-597. (2009) Standard Test Method for Pulse Velocity through Concrete.

[17] ASTM-G57. (2012) Standard Test Method for Field Measurement of Soil Resistivity Using the Wenner Four Electrode Method.

[18] AISI. American Iron and Steel Institute.

[19] CYTED-LAST. (1998) Thematic Network XV. Armor Durability, Inspection Manual, Assessment and Diagnosis of Corrosion in Reinforced Concrete Structures. SECOND, p. 128.

[20] Rodríguez Gómez, F. (2000) Resistencia a la Polarización. Dept. Ing. Metalúrgica. UNAM, Mexico.

[21] Tres G. and Saborio, E. (2004) Corrosion Rate Evaluation of Copper Grounding Cable Systems Used in Costa Rica at the ICE. Portugaliae Electrochimica Acta. 2004, 345-360.

[22] ASTM-C618. (2003) Standard Specification for Coal Fly Ash and Raw or Calcined Natural Pozzolan for Use in Concrete.

[23] ASTM-E-2465-13. Test Method for Analysis of Ni alloys by X-Ray Fluorescence Spectrometry.

[24] ASTM-C876-09. Standard Test Method for Corrosion Potentials of Uncoated Reinforcing Steel in concrete. 